Canadian Journal of Higher Education

Revue canadienne d'enseignement supérieur

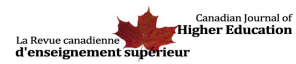

\title{
Student Needs, Employment Realities, and PhD Program Design in Canada: The Case of Planning PhD Programs
}

\author{
Timothy Ross, Julie Mah, Jeff Biggar, Austin Zwick et Ewa Modlinska
}

Volume 48, numéro 3, 2018

URI : https://id.erudit.org/iderudit/1057130ar

DOI : https://doi.org/10.7202/1057130ar

\section{Aller au sommaire du numéro}

\section{Éditeur(s)}

Canadian Society for the Study of Higher Education

\section{ISSN}

2293-6602 (numérique)

Découvrir la revue

Citer cet article

Ross, T., Mah, J., Biggar, J., Zwick, A. \& Modlinska, E. (2018). Student Needs, Employment Realities, and PhD Program Design in Canada: The Case of Planning PhD Programs. Canadian Journal of Higher Education / Revue canadienne d'enseignement supérieur, 48(3), 82-97.

https://doi.org/10.7202/1057130ar

\section{Résumé de l'article}

Les titulaires d'un doctorat au Canada envisagent fréquemment l'idée de travailler à l'extérieur du milieu universitaire. Cet article explore la façon dont les programmes de doctorat sont conçus par rapport aux réalités de l'emploi auxquelles font face les doctorants. Ceci a été rendu possible grâce à une étude de cas effectuée sur les programmes de doctorat canadiens en aménagement. Deux questions sont à la base de cette étude: (1) Comment les programmes de doctorat en aménagement pourraient-ils être repensés afin de mieux préparer les étudiants à de plus vastes options de carrière suite à l'obtention de leur diplôme? Et (2) Quels sont les défis institutionnels qui entravent présentement la réforme des programmes doctoraux? Pour répondre à ces questions, nous avons fait parvenir un questionnaire à des étudiants au doctorat en aménagement de même qu'à plusieurs directeurs de programme, recueilli les commentaires de praticiens en aménagement par courriel, et organisé un atelier ainsi qu'une table ronde lors de deux conférences académiques. Les résultats suggèrent qu'une réforme des programmes de doctorat pourrait entre autres offrir davantage de possibilités de partenariats de recherche externes au étudiants doctoraux, ce qui contribuerait à mieux les soutenir à travers des cheminements de carrière variés. Nos découvertes suggèrent également que les chercheurs universitaires en aménagement de même que les praticiens doivent s'interroger davantage sur la relation qui existe entre les secteurs académiques et professionnels, de même que sur les rôles et objectifs poursuivis par les doctorants.
Copyright (c) Timothy Ross, Julie Mah, Jeff Biggar, Austin Zwick, Ewa Modlinska, 2018
Ce document est protégé par la loi sur le droit d'auteur. L'utilisation des services d’Érudit (y compris la reproduction) est assujettie à sa politique d'utilisation que vous pouvez consulter en ligne.

https://apropos.erudit.org/fr/usagers/politique-dutilisation/ 


\title{
Student Needs, Employment Realities, and PhD Program Design in Canada: The Case of Planning PhD Programs
}

Timothy Ross

University of Toronto

Julie Mah

University of Toronto

Jeff Biggar

Ryerson University

Austin Zwick

Syracuse University

Ewa Modlinska

University of Toronto

\begin{abstract}
$\mathrm{PhD}$ graduates in Canada routinely find themselves considering employment outside academia. This paper explores $\mathrm{PhD}$ program design in relation to $\mathrm{PhD}$ students' employment realities through a case study of Canadian planning PhD programs. Two questions guided the study: (1) How could planning PhD programs be redesigned to prepare students for a wider variety of career options post-graduation? And (2) What are some of the institutional challenges hindering PhD program reform? To engage these questions, we surveyed planning PhD students and program directors, gathered email input from planning practitioners, and held a workshop and roundtable at two different academic conferences. Findings suggest that program reforms, such as offering more external research partnership opportunities to PhD students, could help
\end{abstract}


to better support multiple career pathways for PhD students. Our findings also suggest that planning scholars and practitioners need to question their views of the academia-practice relationship and $\mathrm{PhD}$ students' roles and aims.

\section{Résumé}

Les titulaires d'un doctorat au Canada envisagent fréquemment l'idée de travailler à l'extérieur du milieu universitaire. Cet article explore la façon dont les programmes de doctorat sont conçus par rapport aux réalités de l'emploi auxquelles font face les doctorants. Ceci a été rendu possible grâce à une étude de cas effectuée sur les programmes de doctorat canadiens en aménagement. Deux questions sont à la base de cette étude: (1) Comment les programmes de doctorat en aménagement pourraient-ils être repensés afin de mieux préparer les étudiants à de plus vastes options de carrière suite à l'obtention de leur diplôme? Et (2) Quels sont les défis institutionnels qui entravent présentement la réforme des programmes doctoraux? Pour répondre à ces questions, nous avons fait parvenir un questionnaire à des étudiants au doctorat en aménagement de même qu'à plusieurs directeurs de programme, recueilli les commentaires de praticiens en aménagement par courriel, et organisé un atelier ainsi qu'une table rondelors de deux conférences académiques. Les résultats suggèrent qu'une réforme des programmes de doctorat pourrait entre autres offrir davantage de possibilités de partenariats de recherche externes au étudiants doctoraux, ce qui contribuerait à mieux les soutenir à travers des cheminements de carrière variés. Nos découvertes suggèrent également que les chercheurs universitaires en aménagement de même que les praticiens doivent s'interroger davantage sur la relation qui existe entre les secteurs académiques et professionnels, de même que sur les rôles et objectifs poursuivis par les doctorants.

\section{Introduction}

In his influential report, Scholarship Reconsidered: Priorities of the Professoriate, Ernest Boyer (1990) argued that there was an urgent need to revisit what it means to be a scholar. Emphasizing that knowledge is acquired through research, synthesis, practice, and teaching, he called for a broader, more inclusive understanding of a scholar, one that is better connected to practice and societal challenges. Boyer encouraged an understanding that recognizes academic activities beyond research and publication, such as teaching and the integration and application of knowledge (p. 24). Using this line of thinking, he contemplated how doctoral programs often require students to isolate themselves to achieve program milestones, and rarely afford them the chance to observe connections between their thought and action. Boyer wondered, "Would it be possible for graduate students to participate in a practicum experience and, in so doing, be challenged to see the larger consequences of their work and help reconnect the academy to society?” (p. 69). This paper aims to build on Boyer's questioning of doctoral program designs by considering how doctoral education prepares $\mathrm{PhD}$ students to be contemporary scholars in the face of complex employment challenges. Further, we support Boyer's call for a broader, more inclusive 
understanding of scholarship by suggesting PhD program options that could strengthen program relations with practice and community, and also help students to pursue multiple career pathways. To do so, we consider the case of planning PhD programs in Canada.

Planning can be described as the field of study that examines technical, social, and political processes associated with urban, rural, and community development (e.g., building, transportation, and social infrastructure); land use policy and regulation; the protection of natural and cultural resources; and how people relate to and interact with their environments. Six Canadian universities currently have planning PhD programs (University of British Columbia, University of Alberta, University of Manitoba, University of Waterloo, University of Toronto, and McGill University). Some of these programs have been administered for decades (e.g., University of British Columbia and Waterloo), while others were started over the past decade (e.g., University of Toronto and University of Manitoba). While some planning PhD students in Canada are Registered Professional Planners who have returned to pursue further studies, some are not. Moreover, of those who are not Registered Professional Planners, some have completed university planning (or other) programs not accredited by the Professional Standards Board and are therefore ineligible to obtain their Registered Professional Planner certification after gaining two years of professional experience (unlike those who have taken master's programs accredited by the Professional Standards Board). Instead, these PhD students must first demonstrate the equivalent of at least five years of professional planning experience gained through employment in planning before they are eligible to become a candidate member (Professional Standards Board, 2018). While most planning PhD students enter their programs with the aim of pursuing an academic career, some end up working outside academia in private, public, and non-profit sector positions.

Two research questions guided this study: (1) How could planning PhD programs be redesigned to prepare students for a wider variety of career options post-graduation? And (2) What are some of the institutional challenges hindering PhD program reform? To engage these questions, we discuss findings from an exploratory case study that drew upon data from a survey of planning PhD students at one university, a survey of Canadian planning program directors, a workshop and roundtable discussion held at two separate conferences that planning students and faculty regularly attend, and personal email communication with planning practitioners.

This paper contributes to ongoing deliberations at Canadian planning schools regarding potential changes to existing program designs in order to best serve the needs of their PhD students. We hope the findings and discussion help improve understanding of planning PhD students' employment challenges, encourage scholar-practitioner collaboration, and support academic research that is informed by practitioner needs. Producing research that is tied to practitioner needs may not only enhance practice but also increase the visibility of research, faculty, and departments, and consequently attract potential students and funders (Siemiatycki, 2012, p. 151). Lastly, we hope this paper might contribute to other fields' debates about their PhD program designs and how they account for their PhD graduates' employment realities.

The following section outlines current conditions of doctoral programs and the employment of PhD graduates in Canada. We then explain why planning PhD programs were selected as a case study to consider the relationship between $\mathrm{PhD}$ program design 
and $\mathrm{PhD}$ graduates' employment outside academia. A discussion of the research process follows. We then present findings regarding key program reform options, opportunities and challenges, and a concluding discussion that includes recommendations.

\section{Current Conditions: Doctoral Programs and Employment in Canada}

In Canada, the number of $\mathrm{PhD}$ students and $\mathrm{PhDs}$ granted increased between 2002 and 2011 by $73 \%$ and 68\%, respectively (Edge \& Munro, 2015, p. 10). However, tenure-track positions have decreased in number (Social Sciences and Humanities Research Council of Canada, 2013, p. 7). Similar trends have been found outside Canada (see Cyranoski, Gilbert, Ledford, Nayar, \& Yahia, 2011). The trends in Canada mean that only $18.6 \%$ of PhD graduates are working as full-time university professors, and over $60 \%$ of graduates work outside academia (Edge \& Munro, 2015). Jonker's (2016) findings from her study of the employment outcomes of 2,310 $\mathrm{PhD}$ graduates in Ontario were somewhat more positive. She found that six years after graduating, 29\% of the province's 2009 PhD graduates were employed as full-time tenure or tenure-track professors, and that others were working in suitable positions outside academia (e.g., scientists, engineers, and public servants) (pp. 15, 27). Although Jonker's findings are slightly more positive than those of Edge and Munro (2015), it remains that the academic labour market has changed, the number of secure academic positions are in decline, and $\mathrm{PhD}$ graduates now face a "labour market that offers considerably fewer slots than graduates expect and desire” (Acker \& Haque, 2017, p. 112). Having recognized Canada's academic labour market conditions, as well as the fact that PhD graduates face notable challenges transitioning into careers outside academia, Edge and Munro (2015) recommended that Canadian institutions ensure they are preparing PhD students for "satisfying and rewarding careers both inside and outside [the academy]" (p. 9). This recommendation, along with PhD graduates' employment outlook in Canada, raises questions about the hegemonic prevalence of the academic apprenticeship model. The prevailing "one size fits all" approach to PhD education may discount the value of work-ready, applicable skills required by employers outside academia; consequently, this approach may leave some PhD graduates ill-prepared to work in various industry sectors (Enders, 2005). The need to question how PhD program designs prepare graduates for work outside academia is heightened by the realities of professional employers outside academia who struggle to understand the value of hiring PhDs and the skillsets they offer, and question if $\mathrm{PhD}$ graduates have the necessary interpersonal competencies to work in business environments (Morgavi, McCarthy, \& Metcalfe, 2007; Usher, 2002).

\section{Why Planning PhD Programs?}

Scholars have studied planning education (e.g., curriculum, pedagogy, goals) and its ties to planning practice for decades, as demonstrated by the works of Perloff (1957), Friedmann (1987, 1996), Forester (1989), Healey (1991), Sandercock (2003), and others (e.g., Myers \& Banerjee, 2005; Dalton, 2001, 2007; Reardon, 1998, 2005; Baum, 1997; Kaufman \& Simons, 1995). A history of calls for change in planning education direction and program design recognizes shifting views on the skills and competencies required for planners (Myers \& Banerjee, 2005; Seltzer \& Ozawa, 2002; Friedmann, 1987, 1996); the value of reflexivity in planning (Forester, 1989; Schön, 1987); and research methods (Goldstein, 2012; Friedmann, 1996; Kaufman \& Simons, 1995), as well as the importance 
of communication, collaboration, and narrative (Sandercock, 2003; Seltzer \& Ozawa, 2002; Innes, 1997). However, the majority of this literature is geared toward undergraduate and master's programs. Notably less attention has been given to the education of planning PhD students (Goldstein, 2012; Innes, 1993) and, more broadly, to the role(s) of planning scholars outside academia (Siemiatycki, 2012). Little attention has been given to the linkages between Canadian planning PhD students, PhD program designs, and planning practice, even though these linkages are becoming increasingly important due to current employment realities. To engage this gap in the planning education literature, we embarked on an exploratory research project to consider how Canadian planning PhD programs are meeting students' post-graduation employment needs, and how their approach could be improved.

The planning field has characteristics that make it an excellent entry point for inquiring into PhD program designs and how they account for students' potential employment outside academia. The field serves as a theory-practice nexus and is interdisciplinary in nature, as it links social and applied sciences. In turn, planning serves as a good bellwether and case study for exploring new doctoral program designs that would enable graduates to navigate employment realities more swiftly and transition into careers outside academia with greater ease. Also, the scope of planning is undeniably broad; it considers ever-changing economic, social, environmental, and technological realities across local, regional, and global settings. This is not to say that planning PhD programs are representative of all doctoral programs; rather, due to planning's interdisciplinarity and broad analytical scope, a study of the field's PhD program designs and employment realities may be readily understandable, relatable, and useful to those in other fields dealing with similar issues. Further, the field is clearly connected to a profession and, in turn, has a tangible academia-profession relationship worthy of inquiry. Planning is a recognized profession in Canada that is regulated through registration and licensing processes. In Ontario alone, there are over 4,ooo professional planners (Ontario Professional Planners Institute, 2017). Lessons learned about this field's PhD program designs may help to inform decision making about PhD programs in other fields with similar professional relationships (e.g., nursing, social work, architecture, and education).

\section{Research Design and Process}

This exploratory research drew upon Stake's (1995) instrumental case study approach, which is used to gain insight into a given issue (e.g., PhD graduates' challenging employment conditions). At the same time, the design was largely informed by Stake's intrinsic case study approach, which is used to gain a deeper understanding of a particular situation, such as understanding how planning PhD students' employment challenges are being (and could potentially be) accounted for in program design. As planning PhD candidates, we recognize that we have some inherent interest in this study. We also recognize that intrinsic case study results typically have limited transferability (Baxter \& Jack, 2008); instead, the primary task is to improve understanding of the case to help "tease out relationships, to probe issues, and to aggregate categorical data" (Stake, 1995, p. 77). With this aim in mind, and to support holistic, contextualized understanding, the study was designed using multiple data sources (Yin, 2012). Data were triangulated to search for points of convergence across the different sources to find emergent themes (Creswell 
\& Miller, 2000, p. 126), and contextualize findings in relation to broader research data and trends (Edge \& Munro, 2015; Rose, 2012). The authors acknowledge that specific quantitative findings were not a goal of this research and that there was no attempt to control for bias (e.g., self-selection).

Data were collected from five sources between March and November 2016. We commenced by utilizing our professional networks to reach out, via email, to request input from 10 senior-level Canadian planning practitioners on the skills and research of planning PhD students. These planning practitioners worked in the private and public sectors, as well as professional organizations. To allow for open and candid feedback, the anonymity of the 10 participants has been maintained. Their responses to the three questions below were used to help inform two survey designs:

1. Based on your professional experience, what are some challenges for planning PhD students to be competitive in job markets outside academia (e.g., in planning practice)?

2. What might academia, professional organizations, and employers consider or question in order to advance the value of doctoral students' research outside academia?

3. What are some potential steps that could be taken by academic programs, professional organizations, and employers that could support planning PhDs pursuing careers outside academia?

Survey One was conducted with planning and geography PhD students at a Canadian university. The survey's objective was to understand the students' perspectives on career goals and $\mathrm{PhD}$ program experiences, as well as their viewpoints on PhD program design and employment outside academia. While geography PhD students do not necessarily fit tidily into the study of planning PhD programs, their input was sought since they have crossover in research interests, participate in a comparable $\mathrm{PhD}$ program, and have similar employment concerns. This survey was administered online via SurveyMonkey.com. Using a departmental listserv, a link to the survey was emailed to all planning and geography PhD students. A follow-up reminder was sent two weeks after the initial email. No participation incentives were offered. The questions were predominantly open-ended to provide respondents with ample opportunity to express their views and to offer researchers data that could be mined for emergent themes (Creswell, 2003, p. 18). In total, $30 \mathrm{PhD}$ students responded (25\% response rate) out of the total 118 enrolled.

Survey Two was conducted with planning program directors in Canada. The aim of this survey was to ask respondents about their graduates' employment trends and the integration of professional and practice-oriented opportunities into their PhD planning programs. Like Survey One, this survey was administered via SurveyMonkey.com and no incentives were offered. The survey link was sent directly to program directors via email and, after two weeks, follow-up emails were sent to those who had not responded. In total, we received responses from four out of six Canadian planning PhD programs. Because the small number of Canadian planning PhD programs could enable a reader to identify the speaker if program directors were directly quoted, to protect their anonymity we include no such quotes. Instead, we consider their input in broad terms. Planning program directors in the United States were also surveyed due to the small number of Canadian planning PhD programs. This was done with a view to checking our understandings and 
comparing issues and input in the American context for future research. For context, 17 of the 43 identified United States planning PhD program directors responded and their responses were generally consistent with their Canadian counterparts.

In 2016, we conducted a workshop involving 17 participants and a roundtable discussion involving eight participants. The two events were conducted at separate annual academic conferences regularly attended by Canadian planning students and faculty. The workshop was used to conduct small group discussion exercises concerning the current state of doctoral education for planners and geographers. The roundtable discussion was focused on checking our understanding of planning $\mathrm{PhD}$ program issues and potential options for improvement regarding professional development and employment outside academia. Two researchers took highly detailed notes during the workshop and roundtable discussions. Researchers met immediately following both the workshop and roundtable to discuss key issues that were voiced.

Independently, the researchers thematically coded workshop and roundtable notes, practitioner email feedback, and qualitative survey input with a view to identifying emergent themes and issues. This was followed by triangulation-focused discussions where the authors cross-checked their coded data and their own understandings, and also checked for consistency of themes and issues across data sources (Patton, 1999). These themes and issues are examined in the following sections, which discuss this exploratory study's findings.

\section{Challenging Perceptions}

Our analysis revealed inherent issues in how planning PhD students' roles and goals are perceived. For example, planning practitioners indicated that the work of planning $\mathrm{PhD}$ students and graduates is "too academic" and "too removed from every day to be effective" (practitioner \#1, personal communication, April 2016; practitioner \#2, personal communication, April 2016, respectively). One practitioner echoed these sentiments by expressing that PhDs are "by design, usually detached from the world," and noted that they must interact more with people outside the university to be perceived as relevant (practitioner \#3, personal communication, April 2016). An additional response indicated that a planning PhD education is geared toward creating academic researchers, while in practice planners must prove themselves via professional credentials (practitioner \#4, personal communication, April 2016). These statements suggest that some practitioners perceive the role(s) and research work of planning $\mathrm{PhD}$ students as largely separate from practice.

Some practitioners evidently see few roles for planning PhDs in practice, while some faculty indicated that they congruently view their roles as inside academia. Faculty in both the workshop and roundtable recognized that some planning PhD supervisors may be biased against students undertaking applied work that does not achieve academic goals. Most workshop and roundtable student participants were in agreement. It was also observed that faculty hiring practices and promotion criteria may contribute to the (re) production of such biases, as consulting work and grey literature publications are often not accorded the same value as academic publications. The cutting of past ties between planning $\mathrm{PhD}$ programs and professional planning accreditation bodies across Canada may also support this viewpoint by fostering a culture that expects planning PhDs who have not obtained professional planning degrees to be excluded from professional practice. Professional accreditation was previously given to $\mathrm{PhD}$ programs at the University of 
British Columbia (1973-2010), University of Calgary (1998-2005), University of Toronto (1976-82), and University of Waterloo (1968-2014) (Professional Standards Board, 2017). At the time of writing, there are no Canadian planning PhD programs accredited by the Professional Standards Board (Professional Standards Board, 2017).

Some faculty and program directors indicated that planning PhD students should stay the academic path. Others noted that career paths outside academia should not be discouraged. For example, some faculty workshop and roundtable participants indicated that planning PhD program designs need to be flexible and understood anew, and require a shift in approach to account for new realities. It was noted that there is a need to get away from the idea that PhDs should only pursue academic careers in favour of a more positive and meaningful approach toward PhDs interested in pursuing careers in practice.

When asked about their first-choice career path, over two-thirds of surveyed PhD students indicated an academic career path, while some indicated a preference for careers outside the academy. Despite this interest in career paths outside academia, along with the likelihood of pursuing such careers due to employment realities, the surveyed $\mathrm{PhD}$ students indicated that some faculty seem biased against applied research in academia, recounting numerous instances where supervisors criticized applied research design in favour of more theoretical research. In addition, less than half of $\mathrm{PhD}$ student survey respondents indicated they were comfortable discussing non-academic career paths with their supervisors. Students' reasons for discomfort included feeling that non-academic paths are outside the scope of their relationship, fearing that raising the topic might negatively affect future academic opportunities, and that admitting interest in, or preference for, a non-academic position might disappoint their supervisors. Similar sentiments were reiterated by $\mathrm{PhD}$ students in the workshop and roundtable discussions. The discomfort felt by students interested in a career path outside academia indicates that some planning PhD programs discount or discourage practice as an option and maintain unquestioned values and expectations about PhD students' roles and career aims.

Planning scholars, PhD students, and practitioners should perhaps be encouraged to question their everyday perceptions of, and attitudes toward, one another and, specifically, PhD students' roles and goals. It could also be beneficial for these parties to question their conceptualizations of planning research and practice, and how their relationship is in fact dialectical in nature. In other words, it could be helpful to recognize that there is a false dichotomy between theory and practice (hooks, 1994), as research informs practice and vice versa. Strengthening the linkages between planning academia and practice could be invaluable at a time when PhD students often end up in careers outside academia, and planning practice is increasingly rife with complexity (e.g., environmental, economic, social, and technological challenges) and "wicked problems" (Rittel \& Webber, 1973). Given these circumstances, practitioners could benefit from the work and specialized knowledge of planning PhDs. Plus, planning PhD students, planning scholars in general, and practitioners could all benefit from research informed by practitioner needs.

\section{External Research Partnerships for PhD Students}

Boyer (1990) observed that research and publishing have been viewed as the "most essential form of scholarly activity" (p. 15); thus, they are highly prized in terms of academic advancement. He argued that while these scholarly activities of discovery are important, 
it is equally important for scholars to "think about the usefulness of knowledge, to reflect on the social consequences of their work, and in so doing gain understanding of how their own study relates to the world beyond the campus" (p. 69). Connecting planning PhD students' work to practice through external research partnerships could help them to reflect on the usefulness and social consequences of the knowledge they produce.

The $\mathrm{PhD}$ student survey data suggest that the students have a strong interest in pursuing research partnerships with organizations outside academia. $\mathrm{PhD}$ student input from the workshop and roundtable supported this finding. The idea of developing a collaborative, joint research agenda and project with an outside partner-public-sector organizations first, and private-sector ones second-resonated with many surveyed students' career aims. Addressing students' desires for external research partnerships could help to tie academic research to policy objectives and practice and, in turn, help address some practitioners' view that existing academic planning research is not useful in professional contexts. Moreover, planning scholars and practitioners often think about, define, and engage planning problems differently. Developing external partnerships for planning $\mathrm{PhD}$ students could serve as an opportunity to work toward addressing such differences by establishing common ground between planning scholars and practitioners through mutual learning and collaborative research projects informed by both parties' perspectives.

Our research showed that an absence of departmental frameworks may put students in a challenging position by placing the onus on them to seek out external partnerships with little assistance. While promotional material and program policies for planning $\mathrm{PhD}$ programs may endorse partnerships, there appears to be a disparity between how faculty and students view them. Many student respondents indicated that there are varying expectations between faculty and students about why and how partnerships and applied research components fit into $\mathrm{PhD}$ research. Thus, encouraging discussion to help align student and faculty expectations on this matter could be a practical first step for initiating partnership opportunities and mitigating the burden on students to independently establish their own partnerships. However, initiating this first step may prove challenging, as some faculty do not have much experience with external partnerships, nor do they necessarily have an established network of connections that students could leverage. In such instances, some students endeavour to establish a partnership on their own with minimal support from their supervisors.

The research shows that some planning PhD students have notable interest in pursuing opportunities and developing core competencies along both academic and nonacademic tracks; however, doing so requires a great deal of time and effort, and may jeopardize the timely completion of their PhD. In turn, if external partnerships do not account for program and dissertation requirements, the value and use of the partnerships may diminish. To help address the lack of formal departmental measures pertaining to external partnerships, our research raises the question of their integration into $\mathrm{PhD}$ program designs. For example, planning PhD programs could offer support by developing a framework for identifying municipal planning departments, planning consulting firms, provincial ministries, or external agencies (e.g., regional transportation planning agencies, such as Metrolinx or TransLink; and non-profit policy research agencies, such as the Federation of Canadian Municipalities, the Canadian Centre for Policy Alternatives, and Neptis Foundation) to be involved in students' research design and dissertation-writing 
phases. Involving planning practitioners could create opportunities for them to provide input on the application and policy implications of academic research. For example, the Public Scholars Initiative at the University of British Columbia is a university-wide research collaboration between $\mathrm{PhD}$ students and non-academic partners, which aims to produce applied scholarship for public audiences (University of British Columbia, 2017). In receiving a CAD $\$ 10,000$ grant, students seek partners with mutual interests and work with them to assemble a project that is integrated into their dissertation in the form of a policy development paper, film, web or mapping tool, or exhibition (University of British Columbia, 2017). Such a framework could ease the onus placed on PhD students to identify and create their own ad hoc partnerships and help foster relationships between practitioners and scholars.

Workshop and roundtable participants viewed external partnerships as a potential means of bridging the differences experienced between academia and practice, aligning understandings of planning problems, and producing research informed by practitioners. Thoughtful PhD program reform to support external partnerships was viewed as favourable and preferred over one-off partnerships. The following section considers some opportunities and challenges concerning the realization of program reform.

\section{Recognizing Employment Realities through Program Reform}

Most planning PhD students indicated that their programs could do more in terms of preparing them for their employment realities. More than two-thirds of surveyed PhD students expressed dissatisfaction with the professional development opportunities offered for career paths outside academia. Beyond this, workshop and roundtable input indicated that planning PhD students desire opportunities to make use of faculty's preexisting relationships with practitioners and organizations, gain access to other departments' professional development options, and have planning-specific options. Incorporating professional development options relating to work outside academia could equip students to pursue and transition into work outside academia by helping them to apply their specific knowledge sets and leverage their critical thinking skills in practice settings where they are needed to navigate increasingly complex problems. Calls for PhD program reforms to provide more options for students are not new (Innes, 1993); however, they have often gone unheeded. This may be because implementing changes that emphasize professional development opportunities for careers outside academia presents a unique challenge. It would require a cultural shift across departments because some faculty supervisors, trained for academic positions, may only be comfortable with guiding students toward academic careers (Edge \& Munro, 2015). Beyond this, a lack of initiative to incorporate formalized program elements that account for PhD students' potential career trajectories outside academia may be contributing to a mismatch between planning PhD program designs in Canada and their students' employment realities post-graduation.

The majority of surveyed PhD students noted that their primary motive for pursuing their studies is to enter into a career in academia that combines teaching and research, yet many feel anxious about securing academic employment in light of dim job prospects. Accordingly, many students are left desiring professional development opportunities that support employment outside academia. For example, surveyed PhD students expressed interest in pursuing service learning and internship placements in public and private sec- 
tor settings, external research partnerships, and mentorship programs involving practitioners and scholars who engage in applied research. These preferences reflect a growing desire among $\mathrm{PhD}$ students to acquire a diversity of knowledge, experience, and skills while still pursuing an academic career. Most surveyed students indicated that they were employed in the public or non-profit sectors immediately prior to their PhD studies, and indicated a willingness to return to these sectors as a second-choice option. This willingness aligns with previous research (Béret, Giret, \& Recotillet, 2003; Fox \& Stephan, 2001) on doctoral candidates' employment preferences.

It appears that various Canadian planning PhD programs operate within organizational frameworks where the university, and not individual departments, is responsible for providing professional development and partnership opportunities to graduate students. Accordingly, PhD students are often left to pursue university-wide opportunities on their own. This common practice can place administrative and knowledge-gathering burdens on students trying to obtain increasingly important practice-oriented skills and experiences. Arguably, this practice may allow departments to abdicate or reduce responsibility for integrating a diversity of knowledge, opportunities, and skills into $\mathrm{PhD}$ programs. If departments developed tailored opportunities and integrated them into $\mathrm{PhD}$ program designs, it could be enabling to those students trying to simultaneously enhance their academic and practice-oriented knowledge and skills. Such reform could help to relieve students' concerns about future employment and demonstrate departments' commitments to their students' success post-graduation, both inside and outside academia. Moreover, it could support the advancement of Boyer's (1990) inclusive understanding of scholarship, which embraces synthesis between academia and practice.

In implementing program changes to support PhD students' future employment, departments (and their students) would likely benefit from seizing (or creating) opportunities to undertake detailed assessments of how they are currently addressing students' employment-related needs and desires, as well as the best ways they could tailor and incorporate changes into their specific program frameworks. In doing so, departments could benefit from engaging students and faculty to help ensure that changes are desired and feasible to implement. Further engagement with planning practitioners or other related $\mathrm{PhD}$ programs and departments could help with identifying collaboration opportunities and efficiencies with respect to professional development offerings. Developing and implementing changes that support PhD students' varying needs will require identifying the administrative level(s) (e.g., program, department, school of graduate studies) at which change(s) should be implemented, as well as the best tool(s) for implementing each option (e.g., as a mandatory program component, elective course, curriculum/ course stream option, or supplementary option). What is clear is that planning PhD students have shown a palpable desire for program reforms that align with their efforts to enhance their academic and practice-oriented skills so that they may better navigate the employment realities of $\mathrm{PhD}$ graduates in Canada.

\section{Conclusion}

This paper presented findings from an exploratory study of planning $\mathrm{PhD}$ programs in Canada and their relationship to their students' employment realities post-graduation. In considering the case of planning $\mathrm{PhD}$ programs, we have found that planning $\mathrm{PhD}$ 
students face an uphill battle in challenging how practitioners and even some faculty perceive their roles and goals. Beyond this, we found that planning PhD students desire more opportunities for external research partnerships and professional development opportunities. More broadly, this study has found that these matters warrant attention to satisfy $\mathrm{PhD}$ students' desire for planning PhD program reforms that better account for their employment realities in Canada. Our findings are aligned with broader trends identified in other studies (Edge \& Munro, 2015; Social Sciences and Humanities Research Council of Canada, 2013; Rose, 2012) that documented employers' (mis)perceptions about the value and preparedness of PhDs when transitioning to careers outside academia. Challenges persist for $\mathrm{PhD}$ programs in planning. These include cultural barriers in academia, and the need to reform doctoral education to support multiple career pathways and to articulate the valuable skills of PhDs to employers outside academia (Edge \& Munro, 2015). Importantly, this research confirms that the hegemonic prevalence of the academic apprenticeship model is omnipresent in Canadian planning PhD programs.

Our findings suggest there is need for a cultural shift both inside and outside the academy. Planning scholars and practitioners should revisit their perceptions of the academic-practice divide and embrace the idea that without theory there is no practice, and vice versa (hooks, 1994). In embracing Boyer's (1990) schema of scholarship (discovery, integration, application, and teaching), the apprenticeship pedagogical model that currently holds sway in many $\mathrm{PhD}$ programs must be expanded and, in doing so, open up and reconnect academia to practice and the community. Re-orienting doctoral programs and, more broadly, academia in such a way is especially needed at a time "in which huge, almost intractable problems call for the skills and insights only the academy can provide" (Boyer, 1990, p. 23). Our research suggests that $\mathrm{PhD}$ programs in planning are well positioned to lead the way in orienting scholarship toward practice and community. To begin strengthening ties between planning academia and practice, we recommend that consideration be given to three measures: (1) developing and including a planning profession-accredited stream in planning $\mathrm{PhD}$ programs; (2) establishing formal collaborative partnerships between PhD students ${ }^{1}$ and external bodies (e.g., municipal and provincial governments/ agencies, non-profits, and private sector companies); and (3) implementing systematic tracking tools for monitoring the employment of $\mathrm{PhD}$ graduates. The first measure arises from the problem identified in the "Challenging Perceptions" section, which discussed the cutting of ties between planning $\mathrm{PhD}$ programs and professional planning accreditation bodies across Canada that has served to reinforce the perceived divide between practice and academia. The second recommendation is based on our findings that indicate planning $\mathrm{PhD}$ students desire external research partnerships, but encounter difficulties in pursuing them. The final recommendation emerges from our survey of planning program directors. In the survey, responses to a question about $\mathrm{PhD}$ graduates' employment outcomes indicated a lack of systematic tracking of PhDs' employment post-graduation. The first two measures could give planning $\mathrm{PhD}$ students clearer pathways to careers outside academia, as well as opportunities to conduct research informed by practice and create relationships with external bodies prior to graduating. The third measure could help departments to develop $\mathrm{PhD}$ alumni networks both inside and outside academia that could be used to support mentoring programs. 
Our exploratory study's findings and recommendations demand further research. For example, further research might focus on uncovering and explicating systemic (e.g., conceptual, attitudinal, and values-related) and systematic (e.g., administrative and procedural) barriers to planning (and other) $\mathrm{PhD}$ program change across universities. Additional research could include further case studies of $\mathrm{PhD}$ program designs in other fields that are strongly connected to a profession (e.g., nursing, social work, architecture, and education) or inquiring into their program goals, pedagogical approaches, and faculty hiring and support practices.

To achieve successful planning (and other) PhD program reforms that enable students to pursue multiple career pathways and better navigate employment realities, any change must be made cautiously. This may involve departments engaging and obtaining input from more parties than usual (e.g., students and graduates, other university departments, and administrative bodies; public, non-profit, and private-sector bodies), as well as considering the usefulness and transferability of approaches used in other fields and universities. Program change requires thoughtful regard for students already facing challenges in terms of completing PhDs in a timely manner, and who may require flexibility when endeavouring to develop professional skills. Remaining aware of $\mathrm{PhD}$ students' challenges, considering the aforementioned recommendations, and pursuing further study of $\mathrm{PhD}$ program design in planning and other fields could help PhD students to remain focused on pursuing careers inside academia, while also equipping themselves for potential careers outside academia.

\section{Declaration of Conflicting Interests}

The authors would like to disclose that they are Canadian planning PhD candidates with varying degrees of interest in pursuing careers outside academia. Consequently, they have some intrinsic interest in the paper's subject matter.

\section{Funding}

The authors received no financial support for the research, authorship, and publication of this paper.

\section{Note}

1. Planning departments often have external partnerships for master's program students, but not necessarily $\mathrm{PhD}$ students. Bolstering existing external partnerships and creating new ones to support PhD students could help these students and could foster relationships between academia and practice.

\section{References}

Acker, S., \& Haque, E. (2017). Left out in the academic field: Doctoral graduates deal with a decade of disappearing jobs. Canadian Journal of Higher Education, 47(3): 101119.

Baum, H. S. (1997). Social science, social work, and surgery: Teaching what students need to practice planning. Journal of the American Planning Association, 63(2), 179188. 
Baxter, P., \& Jack, S. (2008). Qualitative case study methodology: Study design and implementation for novice researchers. The Qualitative Report, 13(4), 543-559.

Béret, P., Giret, J. F., \& Recotillet, I. (June 2003). Trajectories from public sector of research to private sector: An analysis using French data on young PhD graduates. Paper presented at the 15th annual meeting on Socio-Economics, Society for the Advancement of Socio-Economics, Aix-en-Provence, France.

Boyer, E. (1990). Scholarship reconsidered: Priorities of the professoriate. Princeton, NJ: The Carnegie Foundation for the Advancement of Teaching.

Creswell, J. W. (2003). Research design: Qualitative, quantitative, and mixed methods approaches (2nd ed.). Thousand Oaks, CA: Sage Publications.

Creswell, J. W., \& Miller, D. L. (2000). Determining validity in qualitative inquiry. Theory into Practice, 39(3), 124-131.

Cyranoski, D., Gilbert, N., Ledford, H., Nayar, A., \& Yahia, M. (2011). The PhD factory: The world is producing more PhDs than ever before. Is it time to stop? Nature: International Weekly Journal of Science, 472, 276-279.

Dalton, L. C. (2001). Weaving the fabric of planning as education. Journal of Planning Education and Research, 20(4), 423-436.

Dalton, L. C. (2007). Preparing planners for the breadth of practice: What we need to know depends on whom we ask. Journal of the American Planning Association, 73(1), $35-48$.

Edge, J., \& Munro, D. (2015). Inside and outside the academy: Valuing and preparing PhDs for careers. Ottawa, ON: Conference Board of Canada.

Enders, J. (2005). Border crossings: Research training, knowledge dissemination and the transformation of academic work. Higher Education, 49(1/2), 119-133.

Forester, J. (1989). Planning in the face of power. Berkeley, CA: University of California Press.

Fox, M., \& Stephan, P. (2001). Careers of young scientists: Preferences, prospects and realities by gender and field. Social Studies of Science, 31(1), 109-122.

Friedmann, J. (1987). Planning in the public domain. Princeton, NJ: Princeton University Press.

Friedmann, J. (1996). The core curriculum in planning revisited. Journal of Planning Education and Research, 15, 89-104.

Goldstein, H. A. (2012). The quality of planning scholarship and doctoral education. Journal of Planning Education and Research, 32(4), 493-496.

Healey, P. (1991). Researching planning practice. The Town Planning Review, 62(4), 447-459.

hooks, b. (1994). Teaching to transgress. New York, NY: Routledge.

Innes, J. E. (1993). Report of the commission on the doctorate in planning to the Association of Collegiate Schools of Planning: An overview. Journal of Planning Education and Research, 12(2), 168-171.Innes, J. E. (1997). The planner's century. Journal of Planning Education and Research, 16(3), 227-228. 
Jonker, L. (2016). Ontario's PhD graduates from 2009: Where are they now? Toronto, ON: Higher Education Quality Council of Ontario.

Kaufman, S., \& Simons, R. (1995). Quantitative and research methods in planning: Are schools teaching what practitioners practice? Journal of Planning Education and Research, 15(1), 17-33.

Morgavi, A., McCarthy, M., \& Metcalfe, J. (2007). Employers' views of researchers' skills: A comprehensive review of the existing literature into employers' views of the skills of early career researchers. UK Grad Programme. Retrieved from: https://www. dur.ac.uk/resources/cel/views-of-researchers-skills-Sept2007.pdf

Myers, D., \& Banerjee, T. (2005). Toward greater heights for planning: Reconciling the differences between profession, practice, and academic field. Journal of the American Planning Association, 71(2), 121-129.

Ontario Professional Planners Institute. (2017). Who we are. Retrieved from http:// ontarioplanners.ca/Who-We-Are

Patton, M. Q. (1999). Enhancing the quality and credibility of qualitative analysis. Health Services Research, 34(5 Pt. 2), 1189-1208.

Perloff, H. S. (1957). Education for planning: City, state and regional. Baltimore, MD: Johns Hopkins University Press.

Professional Standards Board. (2017). Accredited university planning programs in Canada. Retrieved from http://www.psb-planningcanada.ca/CERTIFICATION/ accreditedplanningprograms.php

Professional Standards Board. (2018). Overview of entry routes to certification. Retrieved from http://www.psb-planningcanada.ca/CERTIFICATION/entryroutes.php

Reardon, K. M. (1998). Combating racism through planning education: Lessons from The East St. Louis Action Research Project. Planning Practice \& Research, 13(4), 421432.

Reardon, K. M. (2005). Empowerment planning in east St. Louis, Illinois. City, 9(1), 85-100.

Rittel, H. W. J., \& Webber, M. M. (1973). Dilemmas in a general theory of planning. Policy Sciences, 4, 155-169.

Rose, M. (2012). Graduate student professional development: A survey with recommendations. St. Catharines, ON: Brock University. Retrieved from http://www. sshrc-crsh.gc.ca/about-au_sujet/publications/SSHRC_Report_Graduate_Students_ Professional_Skills_March_2012_eng.pdf

Sandercock, L. (2003). Out of the closet: The importance of stories and storytelling in planning practice. Planning Theory \& Practice, 4(1), 11-28.

Schön, D. A. (1987). Educating the reflective practitioner. San Francisco, CA: JosseyBass.

Seltzer, E., \& Ozawa, C. P. (2002). Clear signals: Moving on to planning's promise. Journal of Planning Education and Research, 22, 77-86. 
Siemiatycki, M. (2012). The role of the planning scholar: Research, conflict, and social change. Journal of Planning Education and Research, 32(2), 147-159.

Social Sciences and Humanities Research Council of Canada. (2013). White paper on the future of the PhD in the humanities. Montreal, QC: McGill University. Retrieved from http://iplai.ca/wp-content/uploads/2015/o4/white_paper_on_the_future_of_the_ phd_in_the_humanities_dec_2013_1.pdf

Stake, R. E. (1995). The art of case study research. Thousand Oaks, CA: Sage.

University of British Columbia. (2017). Public scholars initiative. Retrieved from https://www.grad.ubc.ca/psi

Usher, R. (2002). A diversity of doctorates: Fitness for the knowledge economy? Higher Education Research \& Development, 21, 143-153.

Yin, R. K. (2012). Applications of case study research. Thousand Oaks, CA: Sage.

\section{Contact Information}

Tim Ross

University of Toronto

tim.ross@mail.utoronto.ca

Timothy Ross is a PhD candidate in planning at the University of Toronto. His current work focuses on childhood disability, school transport, education access, and inclusive design.

Julie Mah is a doctoral candidate in planning at the University of Toronto. Her research examines the problem of affordable housing provision and preservation in gentrifying neighbourhoods.

Jeff Biggar is an adjunct lecturer in the School of Urban and Regional Planning at Ryerson University and a policy planner with the Ontario government. His research focuses on the provision of public benefits in land development. He holds a PhD in Planning from the University of Toronto.

Austin Zwick is Assistant Teaching Professor in the Maxwell School of Public Affairs at Syracuse University. His research focuses on planning and regulation around emerging industries.

Ewa Modlinska is a PhD candidate in planning in the Department of Geography and Planning at the University of Toronto. Her research focuses on public, private, and non-profit sector partnerships in neighbourhood revitalization initiatives. 